\title{
Fiscal Synchronisation or Institutional Separation: An Examination of Tax-Spend Hypothesis in Nigeria
}

\author{
Dauda Olalekan YINUSA*, Adebayo ADEDOKUN \\ Department of Economics, Obafemi Awolowo University, Nigeria \\ *Corresponding author: doyinusa@oauife.edu.ng
}

\begin{abstract}
This paper investigates the position of Nigeria within the various fiscal hypotheses (tax-spend, spend-tax, fiscal synchronization and fiscal neutrality hypotheses) using Granger Causality and Block Exogeneity Wald Test within the framework of Vector Error Correction (VEC) Model. The study established one-directional causality that runs from revenue to expenditure (Tax-Spend Hypothesis). This suggests that current government effort at increasing tax revenue is a positive development to reduce or revert the economy from fiscal deficit path. By implication the ongoing government policy towards increase tax revenue and her decision to halt fiscal leakages would sail the economy through the current fiscal crises that are motivated by global crash in the price of crude oil.
\end{abstract}

Keywords: revenue and expenditure, tax-spend hypothesis, Nigeria fiscal system

Cite This Article: Dauda Olalekan YINUSA, and Adebayo ADEDOKUN, "Fiscal Synchronisation or Institutional Separation: An Examination of Tax-Spend Hypothesis in Nigeria." Journal of Finance and Accounting, vol. 5, no. 3 (2017): 80-87. doi: 10.12691/jfa-5-3-2.

\section{Introduction}

The tax revenue and government expenditure in Nigeria attracts attention of researchers and policy makers, following the current shortage of revenues which is attributed to unprecedented fall in global oil price. Meanwhile, like any other countries, the government attitudes to public policy management have significant effects on the welfare of citizens. The effect has both short and long term implications on the current and future generations, depending on the degree of withdrawal and injection to the economy through tax and expenditure respectively. Government ideally ought to earn what it spends through tax collected from individual economic unit in the country and plans accordingly on how to spend it. In other way, it can determine what are needed to be done in a fiscal year and device the appropriate tax regime to be adopted to get the projects implemented.

The decision of the government within these tax-spend or spend-tax nexus has been documented in literature under various hypotheses. The first is the tax-spend hypothesis and has two alternative views which are Friedman [1] and Buchanan and Wagner [2]. Friedman [1] claimed that if government authorities increase taxes, the resources that would be available for the government would be increased, in an attempt to reduce budget deficits and there will only be an increase in government spending. Payne [3] in view of this suggested that indeed, if revenues have positive effects on expenditures, reductions in revenues would in turn reduce government expenditures. The second view is the spend-tax hypothesis, which suggests that a political system determines how much to spend and then makes the adjustments in tax policy and revenue sources in order to finance the government spending. Ricardian equivalence argues that a cut in present taxes leads to higher future taxes with the same value as the initial cut. This happens because government cannot change the present values of taxes but can change present spending. Roberts [4] and Peacock and Wiseman [5] thereafter suggested that temporary increases in government spending because of crisis or war, would have higher permanent taxes as a result.

Narayan and Narayan [6] gave three reasons why the nature of the relationship between government expenditure and revenue is very important. Firstly, if the tax-spend hypothesis is supported, budget deficits can be avoided by implementing policies that stimulate government revenue. Secondly, if the bi-directional causality does not hold, it means that government revenue decisions are made independent from expenditure decisions. This can cause high budget deficits and government expenditure rises faster than government revenue. Finally, if the spend-tax hypothesis is supported, it means that the government spends first and pays for this spending later by raising taxes. This will have as a result a fear of paying more taxes in the future and will encourage the outflow of capital.

The tax and expenditure debate in Nigeria is gathering momentum, following the arguments that expenditure in the country are not informed by the tax collected which are deemed for heading the country towards unprecedented crises aggravated by the crude oil revenue shortage. It is widely accepted that an improvement in the long-run economic efficiency can be achieved by reducing significantly government activities. Excessive government expenditure was believed to stand as the origin of the Grecian financial crisis. In Greece, the government spending to GDP is extremely high and it is believed to have created 
significant inefficiencies in the operations of the Greek economy such as unemployment, high inflation and huge public debt. According to OECD Survey for Greece [7], the country has to modernise its economy by implementing structural reforms that would change the public sector, the labour and product markets and should be closer to international best practices. The efficiency, effort and innovation of Greek workers had to be restored. In the report it was noted that;

"Over a year after a fiscal crisis and the beginning of IMF, EU and ECB support, Greece is still in a serious recession. The sizeable, but vital, fiscal retrenchment, has significantly reduced its large budget deficit. Considerable advances have also been made with structural reforms both in the public sector and in labour and product markets. Despite this progress, persistent market scepticism concerning the capacity of the country to restore sustainable public finances and to renew economic growth has left sovereign interest spreads at record highs" Hagemann ([8], pp23).

It is doubtless that, Nigeria currently suffers fiscal crises, due to shortage of revenues to meet the high propensity of government to spend. Government is believed to have failed to manage expenditures within the frameworks of revenue collected, while some assumed that shortage in the revenue is too much for government to remain functional within tax-spending hypothesis. To the later, tax revenue is a basis for the government spending. However, while the understanding of the cause and effect between tax and spending would assist decision makers in the current state of the economy, it is unfortunate that, the regimes of fiscal operations (Spending and Tax nexus) in Nigeria is yet to be established within the various fiscal hypotheses.

\section{Literature Reviews}

Studies across various countries ends in diverse conclusions. Kalou and Paleologou [9] examined the government revenue and expenditure relationship within the context of soft and hard budget constraint strategy using nonlinear framework with structural breaks, focusing on three countries, Sweden, Greece and Germany. The results indicate absence of any asymmetries for Sweden and Germany, instead, the symmetric ECM provides supports for fiscal synchronization hypothesis in the two countries. An evidence for asymmetries is found in Greece, which in turn support the spend-and-tax hypothesis with asymmetric adjustment towards the long-run equilibrium. The findings indicated that, the Greek fiscal authorities would cut deficits only if it exceeds high "trigger" threshold, which supports soft budget constraint strategy to gain political supports.

In another study, Dizaji [10] investigates dynamic relationships between government revenues and government expenditures in Iran to know how oil price and oil revenue shocks could affect the relationship. The results indicate that the contributions of oil revenue shocks in explaining government expenditures is stronger than the contributions of oil price shocks. The results also show strong causality running from government revenues to government expenditures (both current and capital) in Iranian while the evidence for the reverse causality is very weak. It implies that, the results support tax-spend hypothesis in Iran.

The study on revenue and expenditure nexus in Asia is also documented. Narayan [22] investigate evidence of cointegration and causality between government revenue and government expenditure for nine Asian countries using bounds test approach to cointegration and F-test to examine Granger causality. The results suggest that three out of the nine countries, government revenue and government expenditure is integrated while the directions of causation are mixed. For Indonesia, Singapore and Sri Lanka, short-run causality is found, but the study shows evidence of both a short- and long-run causality for Nepal with strong supports for tax-spend hypothesis. Meanwhile, the study shows that Indonesia and Sri Lanka conform to spend-tax hypothesis in the long-run, while the evidence is neutral for other countries.

The study on the developed economies also show varying pattern. For instance, Saunoris and Payne [11] investigate expenditure and revenue nexus in UK using asymmetric error correction model within a momentum threshold autoregressive framework and found that government revenues respond to short-run changes in government expenditures as well as asymmetrically to budgetary disequilibrium. In the estimated asymmetric adjustment, the response of government revenues to a worsening budget is faster in absolute terms than to an improving budget. The study therefore, contrary to previous studies on the UK, support spend-tax hypothesis

More also, Mahdavi and Westerlund [12] argued that most state and local governments in the U.S. operate under formal fiscal rules which limit their ability to run budget deficits and resort to debt financing, which support their evidence in favor of an intertemporally balanced budget, or fiscal sustainability, for the states, especially those characterized by a relatively high degree of fiscal stringency. In another related study, Westerlund, Mahdavi and Firoozi [13] re-examined tax-spending nexus using a panel of 50 US state and local government units and find that unlike tax revenues, expenditures adjust to revert back to a long-term equilibrium relationship. Their evidence on the short-term dynamics is also consistent with tax-and-spend hypothesis. The implication is that the size of government at the state and local level is not determined by expenditure demand, but rather by resource supply. The study shows that many US state and local governments operate under constitutional or legislative limitations that seek to constrain deficits.

It is however maintained in literature that fiscal policy actions are anticipated to a large extent, because of the existence of legislative and implementation lags. In other words, agents receive signals about future changes in taxes and government spending well before these changes actually take place $[14,15]$.

\section{The Trend of Revenue and Expenditure}

The trend of revenue and expenditure in Nigeria assist in visual examination of pattern of the fiscal behavior across various regimes in the economy. The examination assists in two ways, first it helps to ascertain the possible 
regime shift which could introduce breakpoints to the data and consequently cause spurious findings. Secondly, the historical perspective of behavior of the data assists in policy projection that could augment the econometric findings through the analysis.

Nigeria is one of the countries with poor spending culture in the world for its frequent extra budgetary allocations and the allegations of high incidence of corruption, Sala-i-Martin and Subramanian [16]. It is believed that Nigeria fiscal expenditure profiles grossly violate laid down procedures in accumulation and expenditure of public funds to the detriment of not only the development of the nation, but also against the principles of natural justice.

The sharp decline in the revenue and expenditure in early 1980s could be traced to emergence of Structural Adjustment Program (SAP) introduced as measure to curb financial crisis that followed the collapse of global prices of primary products. The revenue reduction that followed the crashed oil price in the international market gave rise to the debt management problem in the early 80s. The huge debt servicing payment gulp significant portion of incomes, thereby creating serious balance of payment problems for the country. Economic growth was negatively steady, with external reserves drawn down. Shortly, debt servicing and loan repayment became a great burden with unprecedented decline in foreign exchange and the attended stagnation in the private sector. The introduction of structural adjustment program and fiscal restructuring to halt the declining trend was introduced in 1986 which provide explanations for the recovery trend observed in the graph presented in Figure 1. A unique regime shift could also be observed in 1999 which marks the end of military era and transition into democratic governance in the country. There is no other significant trend shift thereafter except in 2008 which marked the global financial crisis period. Meanwhile, the effect of the crisis could be observed more on the revenue trend and not on the expenditure.

The main take on the trend analysis is the possibility of data instability which points to a need for structural break test and consequently correct for the same as might be necessary to avoid spurious findings in the econometric process.

\section{REVENUE GRAPH}

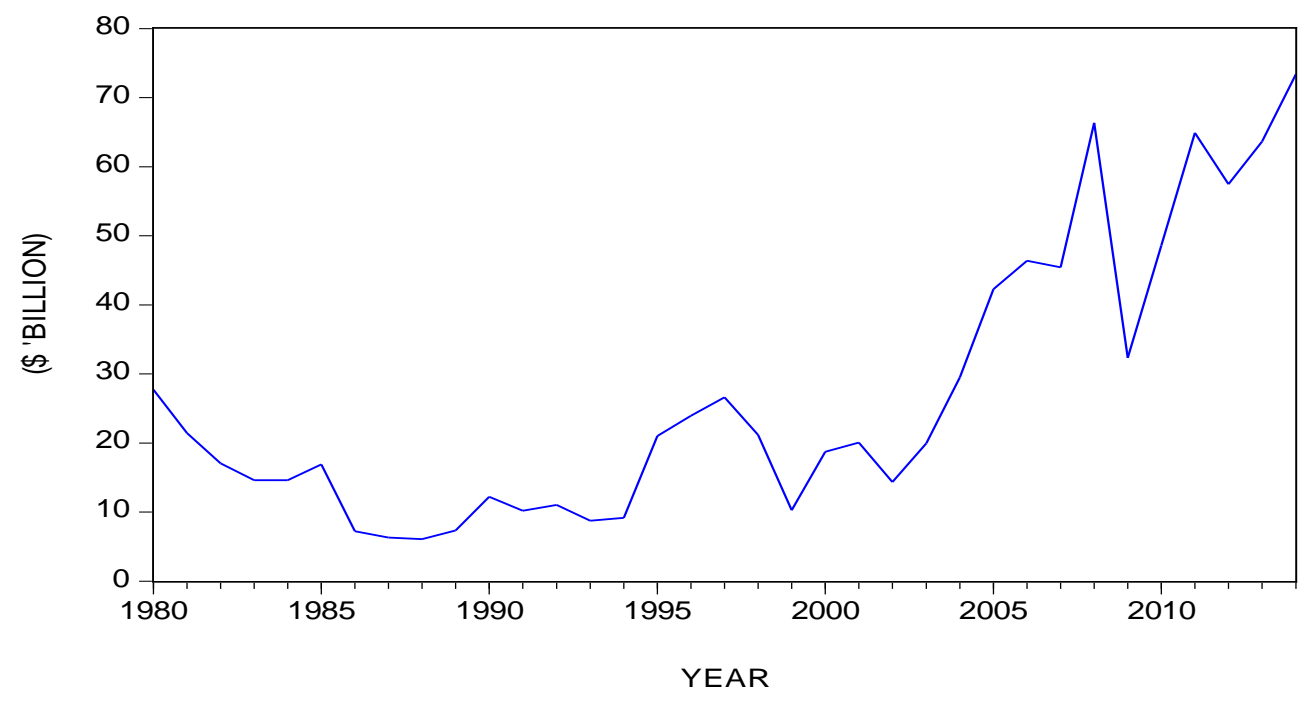

\section{EXPENDITURE GRAPH}

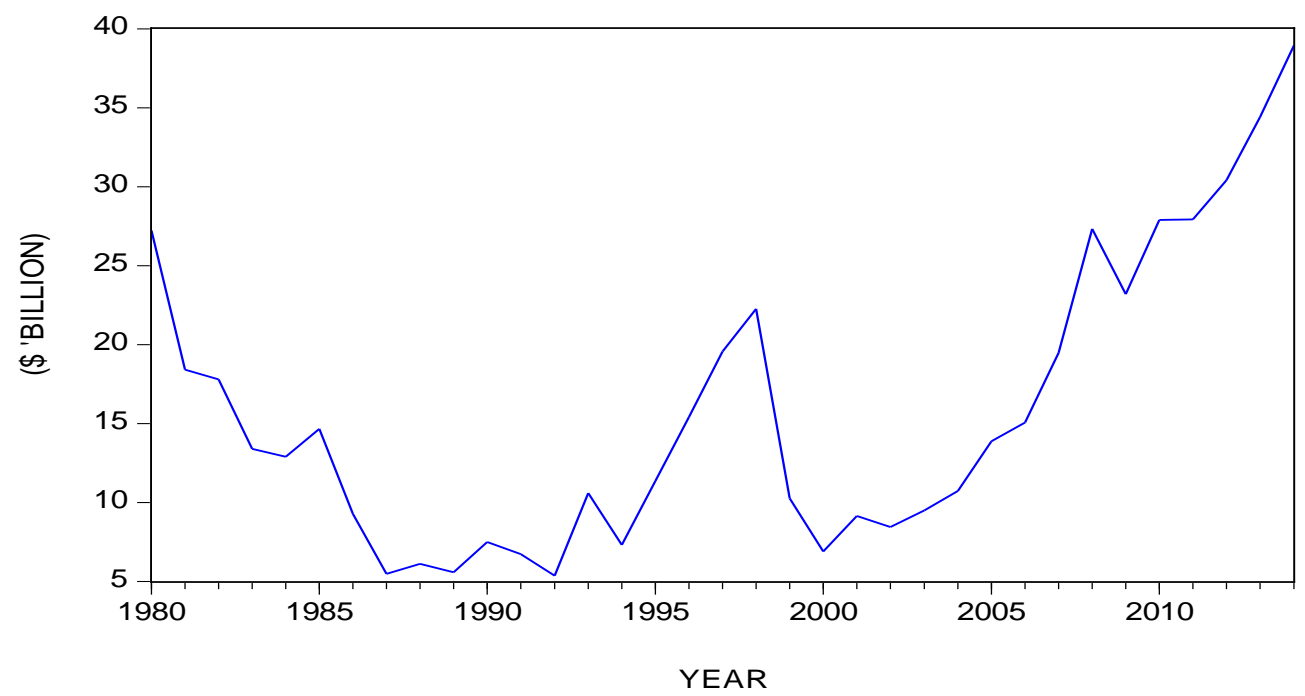

Figure 1. The Trend of Revenue and Expenditure in Nigeria 


\section{Model and Econometric Procedures}

\subsection{Recursive Residual Tests for Structural Breaks}

To test for structural breaks in variables, the recursive test for stability was conducted using both the CUSUM test to ascertain the stability of the variables and the one-step forecast test to identify where the break(s) exist. The CUSUM test is based on the cumulative sum of the recursive residuals suggested by Brown, Durbin, and Evans [17]. It plots the cumulative sum together with $5 \%$ critical lines. Parameter instability is found if the
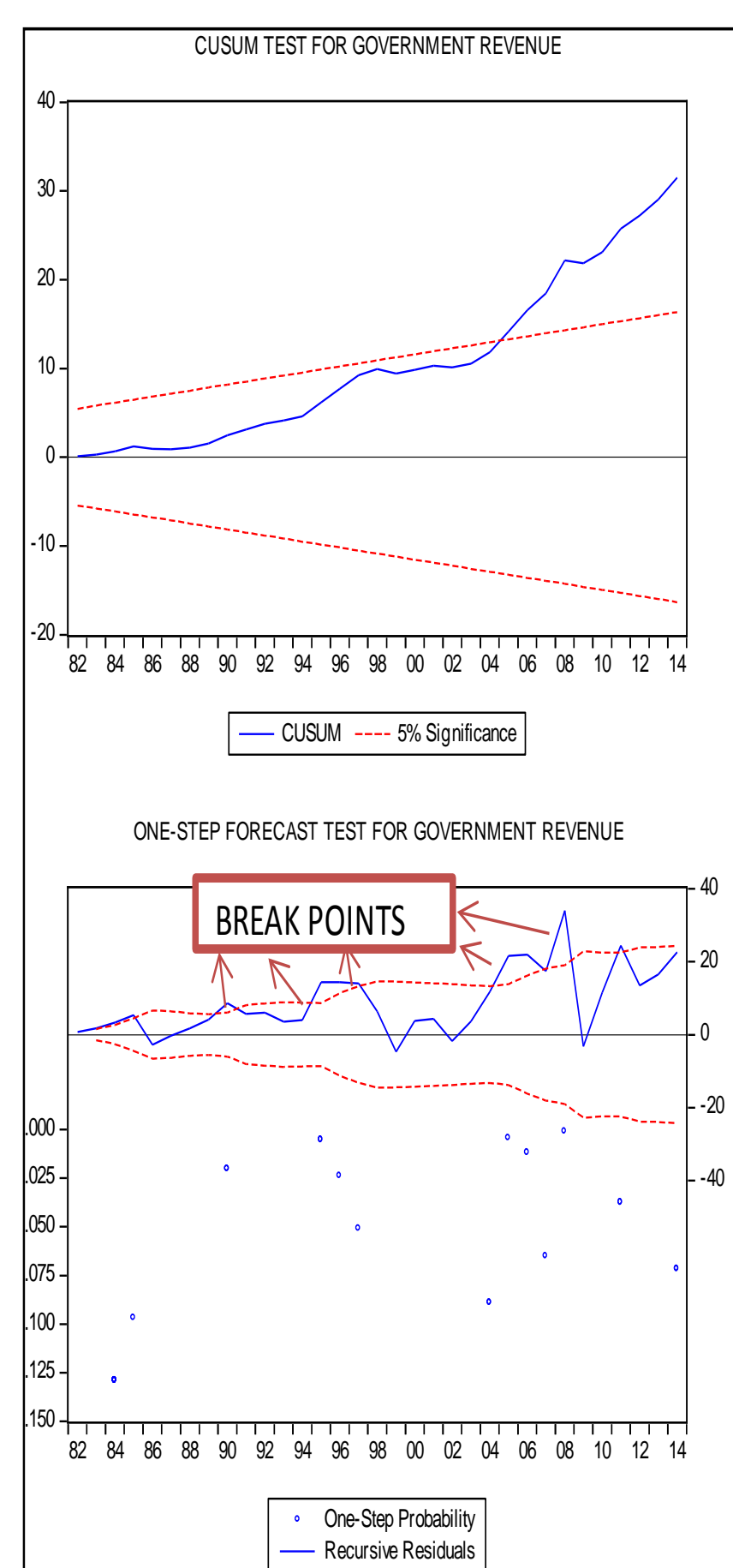

cumulative sum goes outside the area between the two critical lines. As such, movement of the sample of the CUSUM test outside the critical lines suggests coefficient instability. The CUSUM tests results on Expenditure and Revenue is presented alongside the one-step forecast test in Figure 2. The CUSUM tests on the variables shows divergence of the trend outside the 5\% CUSUM boundary. This supports variance instability, which is an indication of existence of structural breaks in the two variables. Consequently, to identify the specific point of the break in the data series, a one-step forecast test conducted helps in identifying the points of instability.
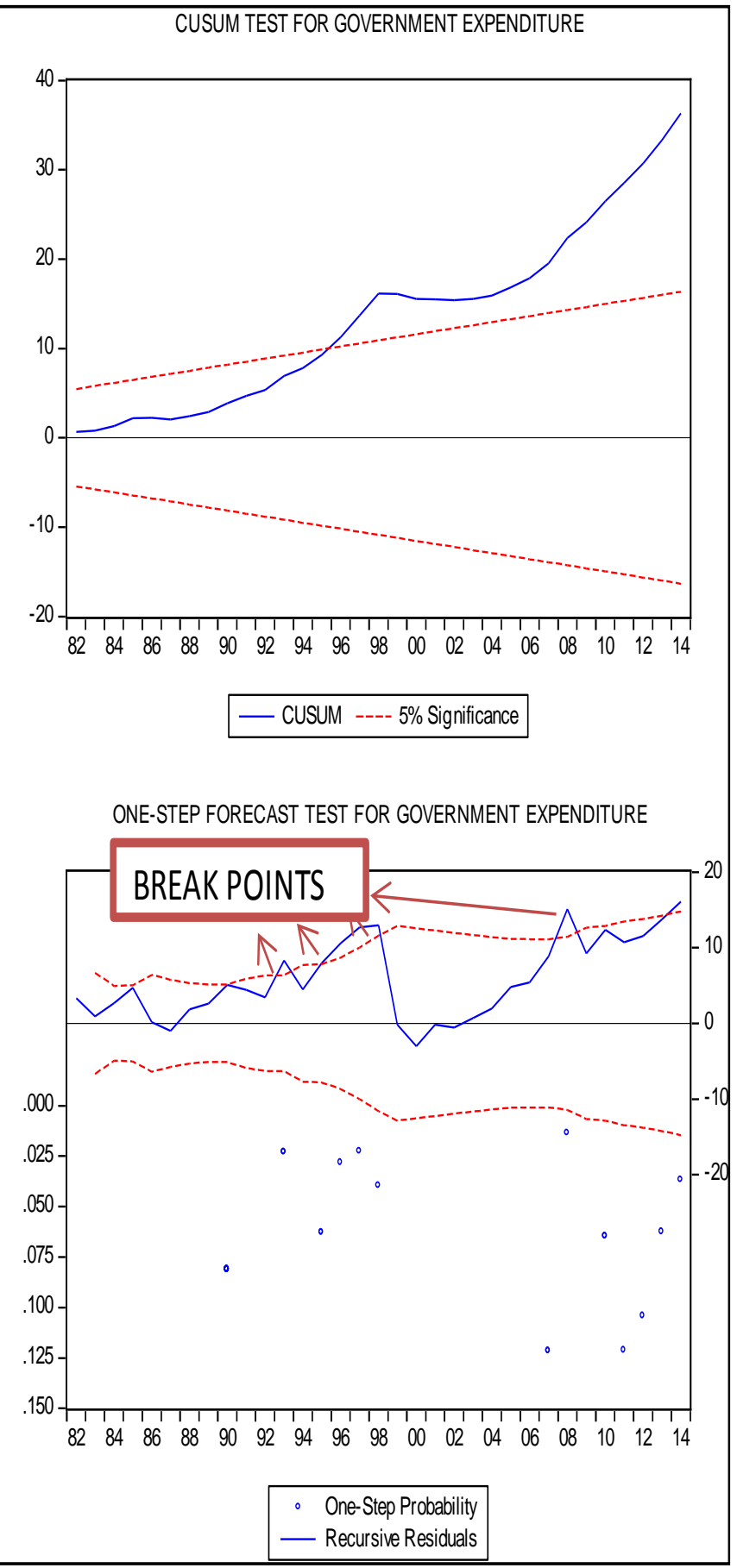

Figure 2. Recursive CUSUM and One-Step Forecast of Revenue and Expenditure 


\subsection{The Econometric Model}

This paper adopts Granger Causality/block exogeneity test between the government revenue (REV) and government expenditure (EXP) within VAR structure.

In the bi-variate VAR describing variable $\mathrm{x}$ and $\mathrm{y}, y$ does not granger cause $x$ if the coefficient matrix $\emptyset_{J}$ are lower triangular for all values of $\mathrm{J}$ :

$$
\begin{aligned}
\left(\begin{array}{l}
x_{t} \\
y_{t}
\end{array}\right)= & \left(\begin{array}{l}
\propto_{1} \\
\propto_{2}
\end{array}\right)+\left(\begin{array}{ll}
\varnothing_{11}^{1} & 0 \\
\varnothing_{21}^{1} & \varnothing_{22}^{1}
\end{array}\right)\left(\begin{array}{l}
x_{t-1} \\
y_{t-1}
\end{array}\right) \\
& +\left(\begin{array}{ll}
\varnothing_{11}^{2} & 0 \\
\varnothing_{21}^{2} & \varnothing_{22}^{2}
\end{array}\right)\left(\begin{array}{l}
x_{t-2} \\
y_{t-2}
\end{array}\right)+\ldots \ldots \ldots . \\
& +\left(\begin{array}{ll}
\varnothing_{11}^{\rho} & 0 \\
\varnothing_{21}^{\rho} & \varnothing_{22}^{\rho}
\end{array}\right)\left(\begin{array}{l}
x_{t-\rho} \\
y_{t-\rho}
\end{array}\right)+\left(\begin{array}{l}
\mu_{1 t} \\
\mu_{2 t}
\end{array}\right) .
\end{aligned}
$$

From the first row of the above system, the optimal one-period ahead forecast of $\mathrm{x}$ does not depend on lagged value of $y$ but on its own lagged values, that is;

If

$$
\begin{aligned}
& E\left(x_{t+1} \mid x_{t}, x_{t-1}, \ldots \ldots, y_{t}, y_{t-1} \ldots . .\right) \\
& =\propto_{1}+\varnothing_{11}^{1} x_{t}+\varnothing_{11}^{2} x_{t-1}+\ldots+\varnothing_{11}^{\rho} x_{t-\rho+1} .
\end{aligned}
$$

To implement the test, having the knowledge that the variables are integrated of order 1 , the optimal lag length $\rho$ suggested by various criteria is adopted and eq. 3 below is estimated within the Vector Error Correction structure:

$$
W_{t}=\left(R E V_{t}, E X P_{t}\right)^{\prime}
$$

The $W_{t}$ is the column vector of the variables. Explicitly:

$$
\begin{aligned}
& \Delta R E V_{t}=\alpha_{1}+a_{1} \Delta R E V_{t-1}+a_{2} \Delta R E V_{t-2}+\ldots \ldots \\
& +a_{p} \Delta R E V_{t-\rho}+b_{1} \Delta E X P_{t-1}+b_{2} \Delta E X P_{t-2}+\ldots \ldots \\
& +b_{p} \Delta E X P_{t-\rho}-\gamma_{R E V}\left(R E V_{t-1}-\alpha_{0}-\alpha_{1} E X P_{t-1}\right)+\varepsilon_{t}^{R E V} \\
& \Delta E X P_{t}=\alpha_{2}+a_{1} \Delta E X P_{t-1}+a_{2} \Delta E X P_{t-2}+\ldots \ldots \\
& +a_{p} \Delta E X P_{t-\rho}+b_{1} \Delta R E V_{t-1}+b_{2} \Delta R E V_{t-2}+\ldots \ldots . \\
& +b_{p} \Delta R E V_{t-\rho}-\gamma_{E X P}\left(R E V_{t-1}-\alpha_{0}-\alpha_{1} E X P_{t-1}\right)+\varepsilon_{t}^{E X P}
\end{aligned}
$$

Where $R E V_{t}=\alpha_{0}+\alpha_{1} E X P_{t}$ is the long-run co-integrating relationship between the two variables and $\gamma_{R E V}$ and $\gamma_{E X P}$ are the error correction parameters that measure how $R E V$ and $E X P$ react to deviations from long-run equilibrium.

Eq. (4) and (5) shows that the optimal one-period-ahead forecast of $R E V_{t}\left(E X P_{t}\right)$ does not depends on lagged values of $E X P_{t}\left(R E V_{t}\right)$, but its own lagged values.

For possible pairs of $R E V_{t}$ and $E X P_{t}, \rho$ is the optimal lag length adopted. Reported F-Statistic are the Wald-statistic for the joint hypothesis

$$
\mathrm{b}_{1}=\mathrm{b}_{1}=\ldots=\mathrm{b}_{\rho}=0 .
$$

The null hypothesis in eq. (6) states that $E X P_{t}\left(R E V_{t}\right)$, does not granger cause $R E V_{t}\left(E X P_{t}\right)$ in equation (4) and (5) respectively.

If any of the coefficient $b_{i} ; i=1,2 \ldots \ldots . \rho$ is significantly different from zero, null hypothesis (6) is rejected in either or both cases in eq. (4) and (5). In case any of coefficient $\mathrm{b}_{\mathrm{i}}$ is significantly different from zero in both equation (4) and (5), then bi-directional causality holds.

\subsubsection{Data Sources and Measurement}

Time series data on government revenue and expenditure at current price, measured in US dollars over the period from 1980 to 2014 were collected from 2016 update of the World Bank's World Development Indicator (WDI) published on the online data base of World Bank data services. The choice of current values measured in dollars as against the local currency is based on the understanding of high rise in the inflation which could result in excessive over valuation of performances that could be attributed to money illusion. But a more stable currency such as US dollar provides a better trend on the actual values

\subsubsection{Estimation and Analysis}

\section{Unit root Test}

To avoid meaningless statistical inference, it is necessary to ensure that time series data are stationary. If the data are trending, trend removal is required [18]. The most common trend removal or de-trending procedure is first differencing of data. First differencing is appropriate for I(1) time series. Unit root tests are used to determine if trending data should be first differenced or be differenced at higher order to render the data stationary. Phillips and Perron [19] and Augmented Dickey-Fuller (ADF unit root tests are used in this analysis. The Phillips-Perron (PP) unit root tests only differ from ADF tests in how they deal with serial correlation and heteroscedasticity in errors. While the ADF tests use a parametric autoregression to approximate the structure of errors in the test regression, the PP tests ignore any serial correlation in the test regression using non-parametric method. Usually, use of multiple unitroot test approaches is important to provide a robustness check so as to ensure that the limitations inherent in the use of a single approach do not lead to spurious conclusion.

The unit root tests presented in Table 1 show that the two tests ADF and Philip Perron (PP) produce identical results. The presence of unit root could not be rejected at level $\mathrm{I}(0)$ for both the intercept and intercept with trend, but it is rejected for both variables at first difference I(1).

\section{Cointegration Test}

Since all the variables are integrated of order one I(1), cointegration analysis was employed to examine possible long run relationship between the variables. Theoretically, If non-stationary time series data have the same order of integration and there is linear combination of the series, it is referred as being stationary [20]. Cointegration means that time series moves together in the long run, which implies that the error term resulting from the linear combination of time series quantifies the deviation of the time series from their common long-r un relationship and can be used to predict their future values [7]. Johansen technique to test for cointegration among the variables is employed in this study. The results of 'trace statistic' and 'maximum eigenvalue test' as proposed by Johansen [21] are presented in Table 2. 
Table 1. ADF \& Philip Perron Unit Root Tests on Government Revenue and Expenditure

\begin{tabular}{|c|c|c|c|c|}
\hline \multirow[t]{3}{*}{ Variable } & \multicolumn{4}{|c|}{ Unit Root Tests } \\
\hline & \multicolumn{2}{|l|}{$\mathrm{ADF}$} & \multicolumn{2}{|l|}{ PP } \\
\hline & Level & 1st diff. & Level & 1st diff. \\
\hline \multicolumn{5}{|c|}{ With intercept only } \\
\hline REVEN & 0.8723 & $-5.6263 *$ & 0.0757 & $-8.0488^{*}$ \\
\hline EXPEN & -0.4001 & $-5.5160 *$ & -0.7391 & $-5.5192 *$ \\
\hline \multicolumn{5}{|c|}{ With Intercept and Trend } \\
\hline REVEN & -2.6685 & $-6.4520 *$ & -2.48506 & $-9.2897 *$ \\
\hline EXPEN & -2.0867 & $-6.23697 *$ & -2.08675 & $-6.3035^{*}$ \\
\hline
\end{tabular}

ADF is the Augmented Dickey-Fuller test and PP is the Phillips-Perron test. *Indicate rejection of the null hypothesis of non-stationary at $1 \%$, and **indicates stationary at $5 \%$ critical values.

Table 2. Trace and Maximum Eigen Value Cointegration Test among the Price Indexes and Exchane Rate Variables

Trace test indicates 1 cointegrating eqn(s) at the 0.05 level

* denotes rejection of the hypothesis at the 0.05 level

**MacKinnon-Haug-Michelis (1999) p-values

\begin{tabular}{|c|c|c|c|c|c|c|}
\hline & \multirow[b]{2}{*}{ Ho: No of CE } & \multirow[b]{2}{*}{ Eigen Value } & \multicolumn{2}{|c|}{ Trace Test } & \multicolumn{2}{|c|}{ Max. Eigen Value Test } \\
\hline & & & Statistic & $* *$ Prob. & Statistic & **Prob. \\
\hline & & & TEST W & UT DUMN & & \\
\hline \multirow[t]{3}{*}{ REVEN \& EXPEN } & 0 & 0.3511 & 14.3627 & 0.0735 & 14.2741 & $0.0498 *$ \\
\hline & 1 & 0.0027 & 0.0885 & 0.7661 & 0.0886 & 0.7661 \\
\hline & & & TEST W & UMMY & & \\
\hline \multirow[t]{2}{*}{ REVEN \& EXPEN } & 0 & 0.3832 & 16.6577 & $0.0333^{*}$ & 15.9464 & $0.0269 *$ \\
\hline & 1 & 0.0213 & 0.7113 & 0.399 & 0.7113 & 0.399 \\
\hline
\end{tabular}

*Rejection of the hypothesis at $5 \%$ significance level for both the Trace and Maximum Eigen Value Tests. **MacKinnon-Haug-Michelis (1999) $p$ values.

Table 3. Lag Selection Criteria

VAR Lag Order Selection Criteria

Endogenous variables: REVEN EXPEN

Sample: 19802014

Included observations: 29

\begin{tabular}{ccccccc}
\hline Lag & LogL & LR & FPE & AIC & SC & HQ \\
\hline 0 & -210.7941 & NA & 8101.121 & 14.67546 & 14.76975 & 14.70499 \\
1 & -177.2997 & $60.05898^{*}$ & $1061.130^{*}$ & $12.64136^{*}$ & $12.92425^{*}$ & $12.72996^{*}$ \\
2 & -174.2662 & 5.020994 & 1140.494 & 12.70801 & 13.17949 & 12.85567 \\
3 & -170.8168 & 5.233518 & 1199.511 & 12.74599 & 13.40606 & 12.95271 \\
4 & -170.3863 & 0.593874 & 1569.842 & 12.99216 & 13.84082 & 13.25795 \\
5 & -169.4538 & 1.157533 & 2013.702 & 13.20371 & 14.24097 & 13.52857 \\
6 & -161.7556 & 8.494612 & 1652.366 & 12.94866 & 14.17451 & 13.33258 \\
\hline
\end{tabular}

* indicates lag order selected by the criterion

LR: sequential modified LR test statistic (each test at 5\% level)

FPE: Final prediction error;

AIC: Akaike information criterion

SC: Schwarz information criterion

HQ: Hannan-Quinn information criterion.

The results of trace and maximum Eigen value test are not consistent when examined without accounting for the structural break. Not surprisingly, the trace test does not support the existence of cointegration, while Max Eigen Value test does. But when the structural breaks are accounted for, the two tests support the existence of cointegration among the variables. This implies there is long run relationship between them. This provided basis to proceed to causal analysis between the two variables.

Meanwhile, the choice of lag length plays critical role in causality test. Therefore, the choice of appropriate lag length is subjected to various lag length selection criteria. The result is presented in Table 3 .

As presented, all criteria select lag length 1 for the causal analysis. Consequently, the causality test is carried out and result is presented in Table 4. 
Table 4. Government Revenue and Expenditure

VEC Granger Causality/Block Exogeneity Wald Tests

\begin{tabular}{lccc}
\hline \multicolumn{1}{l}{ Dependent variable: D(REVEN) } & & \\
\hline Excluded & Chi-sq & df & Prob. \\
D(EXPEN) & 0.327258 & 1 & 0.5673 \\
& & & \\
\hline Dependent variable: D(EXPEN) & & \\
\hline Excluded & Chi-sq & df & Prob. \\
D(REVEN) & 4.077693 & 1 & $0.0435^{* *}$ \\
\hline
\end{tabular}

** indicates the rejection of null hypothesis of no causality at $5 \%$ significant level.

The causal analysis run unidirectional from revenue to expenditure and it is not the other way round. In other words, revenue is a signal to the expenditure in Nigeria which supports tax-spend hypothesis.

\section{Discussion of Results and Economic Implications}

The study established unidirectional relationship between the government tax revenue and government expenditure in Nigeria. Obviously, the result provides learning point for policy makers and public administrator in the country on the current crises in Nigeria fiscal system.

In any case, if bidirectional causality does not hold, it means government revenue decisions are made independent of expenditure decisions. However the onus of which side of the decision take precedence depends on which of the variable take precedence on the other. However, in this analysis, tax-spend hypothesis prevails. In other words revenue takes precedence on expenditure, which makes it to have strong policy implications for Nigeria economy. More especially during the current financial crises, which are connected to shortfall in the revenue through a crash in the crude oil price in the international market?

Significantly, if the tax-spend hypothesis is supported, budget deficits could be avoided by implementing policies that stimulate government revenue. By implication the government attempt to minimise increase deficit in Nigeria is a possibility, if government enforces and stimulates mobilisation of tax revenue. Historically Nigeria has high propensity for budget deficit even when there were no crude oil crises. This excess in government fiscal management has constituted serious problem in the economy. The main concern has been how to develop actions which could help to change government taste for deficit financing. The present revenue shortfall that result from global oil price crash set in, in the midst of the unresolved problem of incessant extra budgetary spending. The shock forced the government at all levels to consider stimulating tax revenue outside the crude oil and other related products.

The increase in the government agitation to raise revenue through tax using expanded tax base and tax rate has been trailed with criticism. The critics hold various positions. One of the arguments is that the increase in the tax revenue might not necessarily curb the excesses of government spending and thus fail to reduce deficit balances. Another argument is that an increase in the tax revenue might end up creating wider gap between the rich and poor who are already suffering high inequality. The latter is prominent given that the incidence of tax on the impoverished civil servants is higher than those to be suffered by the middle upper and upper class of the society. In Nigeria, it is extremely difficult for civil servants to evade tax due to direct deduction from the sources, while most of the business owners and rich people do not pay various business and personal taxes.

The prediction of ineffective tax policy is therefore premised on the weak institutions. However, while this study does not negate or invalidate the public opinion in its entirety, it thus suggests the effectiveness of tax revenue as a key tool to stimulate the economy and prevent possible deficit financing, especially if the government establishes itself around strong institutions and prevent leakages.

Federal government has demonstrated competences in building strong institution and effectively manage the economy. This is obvious considering various policies the government has and is putting in place since its assumption of office in 2015. For instance, one of the major mandates of the administration is anticorruption crusade. Anticorruption policy is an inevitable foundation for strong institutions in the country given that the country has suffered various fiscal distortions over the past years. As part of the process, federal government is preventing leakages and forcing tax evaders to be responsible to government at all levels. In addition to the strong fiscal policy environment, government is being conservative by preventing excessive government spending on certain items. For instance, there is sharp cut in the proportion of recurrent expenditure compared to capital expenditure. More also, strong audit processes are being institutionalised in various government ministries, parastatals and agencies across the country.

The tax-spend hypothesis established in this study provides further hope to the economy, as it suggests the possibility of reduction in the budget deficit, if government intensifies efforts at increasing tax revenue.

\section{Conclusion}

This study investigates causal relationship between revenue and expenditure using VEC Granger causality and block endogeneity test on Nigerian data. It is carried out to position Nigeria within one of the four fiscal hypotheses; tax-spend, spend-tax, fiscal synchronization and fiscal neutrality hypotheses. The test established one-directional causality which runs from revenue to expenditure (Tax-Spend Hypothesis). This suggests that intensify effort towards increase tax revenue would assist the economy to reduce or revert the economy from fiscal deficit. By implication the ongoing government policy towards increase tax revenue and her actions towards the blockage of fiscal leakages would sail the economy through the current fiscal crises.

\section{References}

[1] Friedman, B. M. (1978). Crowding out or crowding in? The economic consequences of financing government deficits.

[2] Buchanan, J. M., \& Wagner, R. E. (1977). Democracy in deficit. Acad. Press. 
[3] Payne, J. E. (2003). A survey of the international empirical evidence on the tax-spend debate. Public Finance Review, 31(3), 302-324.

[4] Roberts, P. C. (1978). Idealism in public choice theory. Journal of Monetary Economics, 4(3), 603-615.

[5] Peacock, A. T., \& Wiseman, J. (1979). Approaches to the analysis of government expenditure growth. Public Finance Review, 7(1), 3-23.

[6] Narayan, P. K., \& Narayan, S. (2006). Government revenue and government expenditure nexus: evidence from developing countries. Applied Economics, 38(3), 285-291.

[7] Granger, C. W. (1986). Developments in the study of cointegrated economic variables. Oxford Bulletin of economics and statistics, 48(3), 213-228.

[8] Hagemann, R. (2011). How can fiscal councils strengthen fiscal performance?. OECD Journal: Economic Studies, 2011(1), 1-24.

[9] Kalou, Sofia, and Suzanna-Maria Paleologou. (2012). "The twin deficits hypothesis: Revisiting an EMU country." Journal of Policy Modeling 34, no. 2: 230-241.

[10] Dizaji, S. F. (2014). The effects of oil shocks on government expenditures and government revenues nexus (with an application to Iran's sanctions).Economic Modelling, 40, 299-313.

[11] Saunoris, J. W., \& Payne, J. E. (2010). Tax More or Spend Less? Asymmetries in the UK revenue-expenditure nexus. Journal of Policy Modeling, 32(4), 478-487.

[12] Mahdavi, S., \& Westerlund, J. (2011). Fiscal stringency and fiscal sustainability: Panel evidence from the American state and local governments. Journal of Policy Modeling, 33(6), 953-969.
[13] Westerlund, J., Mahdavi, S., \& Firoozi, F. (2011). The taxspending nexus: Evidence from a panel of US state-local governments. Economic Modelling, 28(3), 885-890.

[14] Bi, H., Leeper, E. M., \& Leith, C. (2013). Uncertain fiscal consolidations. The Economic Journal, 123(566), F31-F63.

[15] Mertens, K., \& Ravn, M. O. (2010). Measuring the impact of fiscal policy in the face of anticipation: a structural VAR approach. The Economic Journal, 120(544), 393-413.

[16] Sala-i-Martin, X., \& Subramanian, A. (2003). Addressing the natural resource curse: An illustration from Nigeria (No. w9804). National Bureau of Economic Research

[17] Brown, R. L., Durbin, J., \& Evans, J. M. (1975). Techniques for testing the constancy of regression relationships over time. Journal of the Royal Statistical Society. Series B (Methodological) 149-192.

[18] Zivot, E., 2006. Time Series Econometrics' Lesson Note. ••, University of Washington.

[19] Phillips, P.C.B. and Perron, P., (1988). Testing for a unit root in time series regression. Biometrika 75, 335-346.

[20] Engle, R. F., \& Granger, C. W. (1987). Co-integration and error correction: representation, estimation, and testing. Econometrica: journal of the Econometric Society, 251-276.

[21] Johansen, S. (1991). Estimation and hypothesis testing of cointegration vectors in Gaussian vector autoregressive models. Econometrica: Journal of the Econometric Society, 1551-1580.

[22] Narayan, P. K. (2005). The government revenue and government expenditure nexus: empirical evidence from nine Asian countries. Journal of Asian Economics, 15(6), 1203-1216. 